\title{
Digital Labour Platforms: Financial and Legal Aspects of Sustainable Development
}

\author{
T. Paliyeva ${ }^{1}$, M. Chudinovskikh ${ }^{2, *}$, Y. Kuvaeva ${ }^{2}$, N. Boronenkova ${ }^{2}$ \\ ${ }^{1}$ Mozyr State Pedagogical University Named after I. Shamyakin, Mozyr, Belarus \\ ${ }^{2}$ Ural State University of Economics, Yekaterinburg, Russia \\ *Corresponding author. Email: chud-marina@mail.ru
}

\begin{abstract}
Digital labour platforms are having an increasing impact on the labour market to the economy's current transformation. The question arises as to what extent the digital labour platforms activities will contribute to the achievement of sustainable development goals. The article presents the results of the financial indicators analysis of the largest digital labour platforms in Russia, the specifics of taxation, compliance with labour law and social protection. The main threats to sustainable development include overexploitation of workers, the absence or low level of social guarantees, insufficient financial stability, the risk of bankruptcy, insufficient transparency, and a tendency to monopolize the market. The main way to solve the identified problems can be to combine the efforts of the State and digital labour platforms to ensure the conditions for meeting the sustainable development goals.
\end{abstract}

Keywords: digital labour platforms, labour, regulation, platform employment, social protection, ILO.

\section{INTRODUCTION}

Research interest in platform employment issues began to emerge more than 15 years ago. The digital labour platform (hereinafter referred to as DLP) is a website and/or mobile application through which the interaction between clients and performers is organized. The owner of the DLP is a legal entity. The organization of the DLP activity can be either the main activity of a legal entity or represent only one of the business directions. It is necessary to distinguish the DLP and the legal entity that owns it. Digital labour platforms are most prevalent in the taxi services, freelance, design, IT, delivery, small-task and short-term projects.

In 2020 the number of publications in leading international citation databases dedicated to DLP reached a historical maximum, in part because of the transformation processes in the global labour market under the influence of the pandemic. The main areas of research in world science can be identified as:

- identification of the advantages, disadvantages, opportunities, features of DLP and their impact on social and labour relations $[1,2,3]$;

- analysis of DLP activities features in developing countries [4]
— assessment and new models design of legal regulation of social and labour relations in the framework of platform employment [5];

- defining of the legal status of persons engaged in labour activities through DLP, as well as the rights assessment to social protection, labour protection, resolution of labour disputes [6];

— algorithmic control features [7, 8]

- the impact of platform employment on the health and well-being of workers, including those influenced by the pandemic Covid [9].

Both Russian and foreign researchers pay attention to the presence of a «legal vacuum» in the DLP regulation $[10,11]$. In Russian practice, the concept of «digital labour platform» is still used mainly in scientific literature. [10-13].

\section{MATERIALS AND METHODS}

The rapid development of platform employment requires scientific understanding, as well as the formation of new approaches to legal regulation in order to ensure sustainable economic development. The scientific problem is the lack of knowledge and information about the features of platform employment [13]. ILO reports 
contain a fairly large amount of information about the DLP, but there is practically no mention of Russian analogues there. [14].

The research includes the following stages.

1. Defining the main areas of activity in which the Russian DLPs are represented.

2. Analysis of financial terms of companies that own platforms;

3. Ranking companies by revenue.

4. Defining the impact of the COVID pandemic on financial indicators.

5. Sustainability assessment of the financial model, the impact of digital labour platforms on the labour market.

The main information sources are data from the International Labour Organization, data from Rosstat, data from financial statements of companies published on the portal https://bo.nalog.ru/.

\section{RESULTS}

The Russian legal framework does not yet operate with the concept of «digital labour platform». To distinguish DLPs from the general array of organizations, the ILO methodology was used, which allocates the following types of platforms.

Within the DLP of the first type, services are provided exclusively via the Internet without physical contact or meeting with the customer or contractor. In the second case, the DLP provides the organization of order execution in the real, not the virtual world.

In the Russian Federation, digital labour platforms are represented in the field of taxi services, delivery, as well as in the provision of individual services. In the following, these areas of activity will be referred to as «taxi», «delivery» and «services». The most transparent from a financial point of view is the transport sector. The market leader is Yandex. Taxi LLC. In terms of its indicators, Yandex. Taxi is significantly ahead of all its closest competitors.

Table 2 presents data on the dynamics of revenues of the largest companies, which, according to their model, can be attributed to digital labour platforms. The table is prepared according to the data of the financial statements of the companies.

The presented data indicate a phenomenal increase in DLP indicators. Thus, the market leader Yandex. Taxi has increased its revenue more than 20 times over 5 years - from 2,8 in 2016 to 55,8 billion rubles in 2020 . In the face of the pandemic, a sharp increase in revenue was demonstrated by the largest ready-to-eat meals delivery services - Delivery Club and Yandex. Food. The sharp rise in popularity of DLP is due to a number of factors: manufacturability of services, improved quality and speed of service, convenience for customers, and the ability to scale the business model. Taxi and delivery services are supported by financial investments from large IT companies.

At the same time, the sector of freelance services in Russia remained grey for a long time, without major players. Because of this, the segment of the services and freelancing sector are developing considerably less successful. Among the largest portals for freelancers are sites «Profi.ru», FL.ru, Weblancer.net, Freelance.ru, Kwork, Workspace. In terms of revenue, they are significantly inferior to Yandex. An important problem of freelance exchanges is that many of them are not registered in Russia and operate from the territory of Ukraine, the USA, and the countries of Southeast Asia. This sector is so far the least transparent among all DLPs.

The COVID pandemic is driving DLP revenue growth for several reasons. Lockdowns, restrictions and bans have become an incentive for the development of delivery services. The shift to telecommuting has also stimulated both demand and supply in the teleworking segment, which can be done from home. The data presented show that 2020 was a successful year for most of the major market participants. The development of information technologies, an increase in the provision of mobile phones, tablets will stimulate further growth of DLP.

\subsection{DLP and Labour Market}

DLPs have a significant impact on the transformation of the labour market. The growth in demand for services leads to an increase in the number of platform workers. DLPs provide an opportunity for earning money in many countries of the world, including developing ones. The ability to get quick income at least partially alleviates the

Table 1. Types of digital labour platforms according to the ILO methodology.

\begin{tabular}{|l|l|}
\hline Online web - based & Location - based - platforms \\
\hline Freelance and contest based & Taxi \\
Microtask & Delivery \\
Competitive programming & Home service \\
Medical consultation & Domestic work \\
& Care services \\
\hline
\end{tabular}


urgency of the unemployment problem. The DLP makes it possible to receive income for people with limited mobility, people with disabilities, since some activities can be carried out from home. For employers and customers, DLPs provide access to workforce around the world. All of this contributes to the achievement of one of the sustainable development goals in terms of ensuring decent work. On the other hand, like any new phenomenon, DLPs give rise to a lot of questions and difficulties that require evaluation and solution. International Labour Organization recognizes gaps in platform employment data [14]. The current statistical tools do not allow assessing the scale of platform employment.

Another important issue concerns the status of platform workers. In world practice, DLP is fulfilling the work with two categories: the first is the employees of DLP, who work under an employment contract. Their number is relatively small, usually less than 10 thousand people. These employees carry out mainly activities in the field of management, advertising, finance, accounting. The second category is the orders contractor distributed through DLP. These include drivers, nannies, freelancers, designers and other professionals. According to the data cited by some DLPs, their number can be in the millions. These people either have the status of selfemployed, or are employed by contractors, or act as individual entrepreneurs, or work without any registration at all. The problem is that for a significant part of the performers, the income received from DLP is the main one, and a person can spend more than 8 hours a day on the execution of orders. The labour legislation of most countries cannot yet answer the question of the legal status of the platform worker, which poses a significant threat to sustainable development. Further development of DLP will lead to an even greater deepening of this problem. Finding ways of development, a balance between economic interests and observance of labour rights is the most important task of the scientific community in the medium term.

\subsection{Financial Sustainability of Digital Labour Platforms}

Digital labour platforms have a variety of features in their financial models. Firstly, platforms often emerge as a startup that carries potential risks for both investors and employees. In world practice, the source of funding is either venture capital or large companies that invest from their main sustainable activities in innovative areas. The example of the Yandex company allows us to conclude that taxi services, delivery, micro-tasks are secondary for the company. The main source of income is activities in the field of IT - technologies and advertising. Many companies operating on the Russian market are subsidiaries of international concerns.

Sustainable development of the Russian economy is only possible if DLPs are profitable in the long term. However, an analysis of the financial indicators of DLP shows that in the first years of creation, they are most often unprofitable. At the stage of formation, DLPs attract customers with lower prices, while contractors, on the contrary, are offered more favorable terms of remuneration. After 2-3 years, with an increase in market share, there is a simultaneous increase in prices for customers and a decrease in prices for contractors. On the one hand, this is necessary to ensure financial stability. However, on the other hand, the deterioration of working conditions and wages causes indignation among workers. For example, in July 2020, Delivery Club couriers went on strike over a policy of fines and distribution of orders. As a result of the strike, the company changed its remuneration policy, contractors paid off debts to couriers. Assessing the possibilities of protecting collective labour rights, it should be noted that the current legislation does not provide for the creation of trade unions of platform workers.

Table 2. Revenue of the largest DLP, billion rubles.

\begin{tabular}{|l|l|l|l|l|l|l|}
\hline Company & Kind of activity & 2016 & 2017 & 2018 & 2019 & 2020 \\
\hline $\begin{array}{l}\text { Yandex. } \\
\text { Taxi }\end{array}$ & Taxi & 2,8 & 9 & 26,7 & 46,1 & 55,8 \\
\hline $\begin{array}{l}\text { Delivery } \\
\text { Club }\end{array}$ & Delivery & No data & No data & 1,9 & 4,8 & 10,3 \\
\hline $\begin{array}{l}\text { Yandex. } \\
\text { Food }\end{array}$ & Delivery & No data & No data & 0,9 & 3 & 5,8 \\
\hline Gettaxi & Taxi & 2,4 & 3,6 & 4,7 & 5,5 & 4,7 \\
\hline Profi.ru & Services & 0,07 & 0,9 & 0,8 & 0,95 & 1,2 \\
\hline
\end{tabular}


In some areas (such as taxi and delivery), DLPs monopolize the market. It is important to understand that competitive advantage and bargaining power are not based on an efficient financial model. DLPs often generate losses and are supported by venture capital funds rather than profits in the short to medium term. Supporting unprofitable DLP operations destroys traditional models, making small businesses especially vulnerable. For example, the owners of bus companies complain that taxi aggregators do not comply with the requirements of labour and transport laws, and at the expense of lower prices they are squeezing them out of traditional markets.

\subsection{Taxation and Social Guarantees}

Another contentious issue is the taxation of activities of both digital labour platforms themselves and their employees. An experiment to develop self-employment began in the Russian Federation in 2019. Its legal basis is the federal law of November 27, 2018 N 422-FZ «On conducting an experiment to establish a special tax regime «Tax on professional income». Registration as self-employed allows the contractor to pay tax at a preferential rate of $4 \%$ if the payment comes from an individual and $6 \%$ if the payment comes from a legal entity. The self-employment experiment is focused primarily on large DLPs, including Yandex. Taxi. As of September 1, 2021, more than 3 million people have registered as self-employed in Russia, of which about $30 \%$ are drivers. Representatives of the Federal Tax Service in their interviews point out that cooperation with DLP allows to bring part of the transportation market out of the shadows. However, the self-employed do not pay a contribution to the off-budget funds. This negatively affects the replenishment of their budgets. In addition, workers themselves are deprived of the right to pensions, hospital and other social benefits. The absence of a system of social guarantees is diagnosed by us as a major threat to the sustainable development of the Russian economy in the long term.

The problem of social guarantees is acute for the workers of the DLP in many countries of the world, it is recognized by the ILO. The solution to the problem is possible in several ways. The first way is to establish legal requirements for the provision of social guarantees for platform workers, including at the expense of the DLP funds. However, the financial model of DLP, in which the activity has been unprofitable for several years, can become a serious obstacle to the implementation of this approach in practice. The second option is the introduction of a voluntary insurance system for platform workers. A similar approach is used in Russia as of 2021. Its main disadvantage is the precarization of the selfemployed and a significant deterioration in their position in comparison with workers in traditional industries. The third option is a combination of the principles of compulsory and voluntary insurance, stimulating DLP to behave responsibly. The experience of Yandex can be cited as a positive example. In the face of the pandemic in 2020-2021, an experiment began to provide social guarantees, in particular, analogues of paid hospital and insurance for children and couriers. The sick leave program is 800 rubles per day from the second day of illness, up to 24 thousand rubles per month maximum, and payments from accidents - up to 2 million rubles.

The following table summarizes the opportunities and threats that are associated with the DLP activities.

Awareness of the severity of the emerging problems led to the signing of the "Charter of principles for good platform work" by the leading DLPs [15]. In particular, paragraph 2.2 of the Charter states that platforms should have policies or guidelines that can help protect workers from health and safety risks. Paragraph 3.2 of the Charter specifies that the grounds and procedures for account deactivation must be clear and platforms must work to establish processes for challenging decisions. The Charter also contains a number of other guarantees aimed at improving the legal status of persons carrying out activities through DLP. Uber, Deliveroo, Grab and some others have already joined the Charter. The presented example shows that the lack of legislative regulation at the moment is partially compensated by the development of self-regulation mechanisms. Despite the fact that this approach is traditionally positively assessed by foreign researchers, in the Russian Federation, given the existing system of legal awareness, it is important to establish a

Table 3. Opportunities and threats of DLP in the context of sustainable economic development.

\begin{tabular}{|l|c|}
\hline Opportunities & Threats \\
\hline Introduction of innovative technologies & Overexploitation of workers \\
Improving the quality of services provided & Lack or low level of social guarantees \\
Increase in labour productivity & for platform workers \\
Reducing the severity of the unemployment & Insufficient financial stability, risk of \\
bankruptcy \\
Lack of transparency and information \\
problem
\end{tabular} \begin{tabular}{c} 
Providing work for people with limited \\
Tendency to monopolize the market \\
$\begin{array}{l}\text { Growth in tax revenues due to the reduction of } \\
\text { the informal sectors of the economy }\end{array}$ \\
\hline
\end{tabular}


legislative framework and monitor their implementation. The International Labour Organization also recommends the development of a model based on the provision of guarantees to all workers, regardless of the form of employment.

\section{CONCLUSION}

The rapid development of digital labour platforms provides a range of opportunities for all market participants, but the lack of legal regulation threatens the sustainable development of the economy. Among the main priorities for the development of DLP regulation are:

- creation of conditions for fair competition of DLPs with traditional enterprises;

- ensuring clear and transparent conditions for hiring workers, determining the legal status of contractors, creating a system of social guarantees for platform workers;

— increasing requirements for information transparency of digital platforms in terms of disclosing information on financial indicators, data on labour, wages;

- providing a guarantee of access to the mechanism for resolving labour disputes, the activities of trade unions;

— improving the efficiency of DLP taxation.

\section{REFERENCES}

[1] V. De Stefano, A. Aloisi, Fundamental Labour Rights, Platform Work and Human-Rights Protection of Non-Standard Workers". Labour, Business and Human Rights Law (2019) pp. 359379.

[2] J. Drahokoupil, M. Jepsen, The digital economy and its implications for labour. The platform economy. Transfer, European Review of Labour and Research 23(2) (2017) pp. 103-107.

[3] M. Graham, I. Hjorth, V. Lehdonvirta, Digital labour and development: impacts of global digital labour platforms and the gig economy on worker livelihoods. European Review of Labour and Research 23(2) (2017) pp. 135-162. DOI: https://doi.org/10.1177/1024258916687250.

[4] U. Rani, M. Furrer, Digital labour platforms and new forms of flexible work in developing countries: Algorithmic management of work and workers. Competition \& Change 25(2) (2021) pp. 212- 236. DOI: https://doi.org/10.1177/102452942 0905187.
[5] S. Andrew, S. McCrystal. Labour Regulation and the Great Divide: Does the Gig Economy Require a New Category of Worker? Australian Journal of Labour Law 32 (1) (2019) pp. 4-22.

[6] M. Malin, Protecting Platform Workers in the Gig Economy: Look to the FTC. Indian Law Review 51 (2) (2018) pp. 377-412.

[7] A. Rosenblat, L. Stark L. Algorithmic Labour and Information Asymmetries: A Case Study of Uber's Drivers. International Journal of Communication 10 (2016) pp. 3758-3784.

[8] A. Wood A., M. Graham, V. Lehdonvirta, I. Hjorth Good Gig, Bad Gig: Autonomy and Algorithmic Control in the Global Gig Economy. Work, Employment and Society 33(1) (2019) pp. 56-75.

[9] S. Fabian, V.Dunn, S. Sawyer. Distancing Bonus or Downscaling Loss: The Changing Livelihood of US Online Workers in Times of COVID-19. Journal of Economic and Social Geography 111(3) (2020) pp. 561-573.

[10] N. Lyutov, I,Voitkovska, Remote Work and Platform Work: The Prospects for Legal Regulation in Russia. Russian Law Journal 9(1) (2021) pp. 81113. DOI: https://doi.org/0.17589/2309-8678-20219-1-81-113.

[11] Y.V. Kuvaeva, M.V. Chudinovskikh, N.L. Boronenkova. Approaches Formation to the Regulation of Crowdfunding Platforms, Digital Economy: from Regional Development to Global Economic Growth" (MTDE 2020). DOI: https://doi.org/10.2991/aebmr.k.200502.173

[12] O. Chesalina, Social and Labour Rights of "New" Self-Employed Persons (and in Particular SelfEmployed Platform Workers) in Russia. Russian Law Journal 8(2) (2020) pp. 49-78. DOI: https://doi.org/10.17589/2309-8678-2020-8-2-4978.

[13] O. Chesalina, The scope of labour law in the platform economy. European and Asian Law Review 4(1) (2021) pp. 28-35. DOI: https://doi.org/10.34076/27821668_2021_4_1_28.

[14] International Labour Organization (ILO). World Employment and Social Outlook. The role of digital labour platforms in transforming the world of work (2021).

[15] Charter of principles for good platform work. http://www3.weforum.org/docs/WEF_Charter_of_ Principles_for_Good_Platform_Work.pdf. 